\title{
Improved Mathematics Learning Outcomes on Constructed Flat Material Using PMRI in Grade II SD Negeri 1 Paningkaban Academic Year 2020/2021
}

\author{
Suwarni \\ SD Negeri 1 Paningkaban \\ warninew57@gmail.com
}

\section{Article History}

accepted 14/11/2020

approved 21/11/2020

published 26/11/2020

\begin{abstract}
This study aims (1) to describe efforts to improve student learning outcomes, (2) to describe the use of PMRI to improve trust and learning outcomes. Researchers use PMRI because in the second step (inviting students to solve problems and the third step (facilitating students to express their opinions) can help students become confident. Improving student learning outcomes is pursued through the use of media in the form of flat-shaped objects. This type of research is classroom action research. (PTK), consisting of four steps: planning, implementing, observing and reflecting. There were two cycles conducted by the researcher. The subjects of this study were 15 grade II students of SD Negeri 1 Paningkaban. Data collection techniques used observation sheets and written tests. This research uses quantitative and descriptive qualitative. The results of this study indicate: efforts to improve learning outcomes: from the initial condition 26.67, cycle I to 46.67 and cycle II to 80. Thus the use of PMRI can help students increase their attitude of lack of confidence to become quite confident, also increase yield I student learning on flat wake material.
\end{abstract}

Keywords: Confidence, learning outcomes, PMRI approach

\begin{abstract}
Abstrak
Penelitian ini bertujuan (1) mendeskripsikan upaya peningkatan hasil belajar siswa, (2) mendeskripsikan penggunaan PMRI dapat meningkatkan sikap percaya dan hasil belajar. Peneliti menggunakan PMRI sebab di langkah kedua (mengajak siswa menyelesaikan masalah dan langkah ketiga (memfasilitasi siswa berani mengemukakan pendapatnya) dapat membantu siswa menjadi percaya diri. Meningkatkan hasil belajar siswa diupayakan melalui penggunaan media berupa benda berbentuk bangun datar. Jenis penelitian ini adalah penelitian tindakan kelas (PTK), terdiri dari empat langkah: perencaaan, pelaksanaan, observasi dan refleksi. Ada dua siklus yang dilakukan peneliti. Subjek penelitian ini adalah 15 siswa kelas II SD Negeri 1 Paningkaban. Teknik pengumpulan data menggunakan lembar observasi dan tes tertulis. Analisis data dalam penelitian ini menggunakan kuantitatif dan kualitatif deskriptif. Hasil penelitian ini menunjukkan: upaya peningkatan hasil belajar: dari kondisi awal 26,67, siklus I menjadi 46,67 dan siklus II menjadi 80. Dengan demikian penggunaan PMRI dapat membantu siswa meningkatkan sikap kurang percaya diri menjadi cukup percaya diri, juga meningkatkan hasil belajar siswa pada materi bangun datar.
\end{abstract}

Kata kunci: Percaya diri, hasil belajar, pendekatan PMRI

Social, Humanities, and Education Studies (SHEs): Conference Series https://jurnal.uns.ac.id/shes

p-ISSN 2620-9284

e-ISSN 2620-9292 


\section{PENDAHULUAN}

Dewasa ini, ilmu pengetahuan dan teknologi di Indonesia sangat berkembang pesat. Kebutuhan masyarakat juga makin kompleks, apalagi sekarang adalah era globalisasi dan perdagangan bebas yang menuntut masyarakat untuk mengimbanginya dengan meningkatkan kualitas sumber daya manusia. Pengembangan sumber daya manusia dapat dilakukan, salah satunya melalui pendidikan.

Menurut UU RI No. 20 Tahun 2003 tentang Sistem Pendidikan Nasional, pendidikan adalah usaha sadar dan terencana untuk mewujudkan suasana belajar dan proses pembelajaran agar siswa secara aktif mengembangkan potensi dirinya untuk memiliki kekuatan spiritual keagamaan, pengendalian diri, kepribadian, kecerdasan, akhlak mulia, serta keterampilan yang diperlukan dirinya, masyarakat, bangsa, dan negara. Sedangkan menurut Dimyati dan Mudjiono (2006: 7), pendidikan merupakan proses interaksi yang bertujuan. Interaksi terjadi antara guru dan siswa yang bertujuan untuk meningkatkan perkembangan mental sehingga menjadi mandiri dan utuh.

Oleh karena itu, pendidikan merupakan salah satu jalan yang membantu siswa untuk mengembangkan potensi dan bakat yang dimiliki agar kelak dapat berguna bagi masyarakat, bangsa, dan negara. Pendidikan juga ikut berperan penting bagi perkembangan kehidupan manusia dalam mencapai kesuksesan dan keberhasilan sehingga memajukan perekonomian negara.

Sekolah dasar merupakan tempat pembelajaran untuk mendapatkan pengetahuan-pengetahuan dasar tentang konsep-konsep maupun prinsip pengembangan sikap kritis dan kreatif dimana kemamouan ini menjadi pijakan dalam menempuh jenjang pendidikan lanjutan sampai perguruan tinggi. Kegiatan belajar mengajar merupakan sebuah interaksi yang bernilai pendidikan, diantaranya interaksi edukatif antara guru dan dan anak didik ketika guru menyampaikan bahan pembelajaran kepada anak didik ketika guru menyampaikan bahan pembelajaran kepada anak didik di kelas. Metode maupun media pembelajaran yang diterapkan guru ketika proses pembelajaran di kelas akan sangat menentukan motivasi, aktivitas, kreativitas serta hasil belajar siswa.

Beberapa faktor penting yang menyebabkan tujuan sebuah pembelajaran menjadi benar-benar tercapai yaitu metode pembelajaran, cara memotivasi siswa dan kreatifitas guru. Dalam beberapa masalah, banyak siswa merasa bosan dengan pembelajaran yang tanpa media belajar yang nyata atau alat peraga.

Oleh karena itu, media pembelajaran atau alat peraga menjadi sangat penting dan dibutuhkan guru dalam memperlancar kegiatan pembelajaran. Adanya media pembelajaran akan membuat siswa aktif dan siswa menjadi lebih paham karena terlibat langsung dalam proses belajar mengajar. Pemahaman siswa sangat berpengaruh terhadap hasil belajar siswa. Jadi, siswa harus paham terhadap suatu pelajaran agar memperoleh hasil belajar yang memuaskan. Hal ini menjadikan PR (Pekerjaan Rumah) untuk guru dalam merencanakan kegiatan pembelajaran yang dapat memotivasi siswa untuk belajar dan memahami materi.

Berkaitan dengan hal-hal yang dikemukakan di atas, maka peneliti mengambil judul penelitian "Peningkatan Hasil Belajar Matematika tentang Materi Bangun Datar Menggunakan PMRI di kelas II SD Negeri 1 Paningkaban Tahun Ajaran 2020/2021" Identifikasi Masalah

1. Masih banyak peserta didik yang belum memahami materi bangun datar

2. Proses pembelajaran yang kurang menarik.

3. Penggunaan Metode pembelajaran yang kurang tepat.

Analisis Masalah

Siswa kelas II Sekolah Dasar berada pada tingkat berpikir visualisasi dalam teori Van Hiele. Dalam tingkat berpikir visualisasi, siswa dapat mengetahui bentuk bangun 
datar secara keseluruhan, namun belum dapat menentukan sifat dari bangun datar. Selain itu, siswa memiliki kemampuan untuk berpikir dengan pemikiran yang nyata atau konkret, sehingga diperlukan pendekatan atau model pembelajaran yang dapat membantu mengatasi permasalahan dalam kegiatan pembelajaran

Rumusan Masalah

1. Bagaimana upaya peningkatan hasil belajar pada materi bangun datar menggunakan PMRI untuk siswa kelas II SD Negeri 1 Paningkaban?

2. Apakah penggunaan PMRI dapat meningkatkan sikap percaya diri dan hasil belajar pada materi bangun datar siswa kelas II SD Negeri 1 Paningkaban berikut:

Berdasarkan rumusan masalah diatas, tujuan dalam penelitian ini adalah sebagai

1. Menjelaskan penggunaan PMRI dalam upaya meningkatkan hasil belajar pada materi bangun datar siswa kelas II SD Negeri 1 Paningkaban.

2. Mengetahui penggunaan PMRI dapat meningkatkan sikap percaya diri dan hasil belajar pada materi bangun datar siswa kelas II SD Negeri 1 Paningkaban

3. Penelitian ini diharapkan dapat memberikan manfaat bagi orang lain. Berikut ini manfaat dari penelitian ini:

a. Manfaat teoritis

Menambah jumlah referensi yang berkaitan dengan PMRI dalam pembelajaran.

b. Manfaat praktis

1) Bagi sekolah

Memberikan referensi kepada sekolah mengenai PMRI untuk meningkatkan sikap percaya diri dan hasil belajar siswa.

2) Bagi guru

Memberikan inspirasi bagi guru dalam meningkatkan sikappercaya diri dan hasil belajar siswa

3) Bagi siswa

Meningkatkan sikap percaya diri dan hasil belar siswa pada materi bangun datar

4) Bagi peneliti

Memberikan pengetahuan dan pengalaman baru dalam menggunakan PMRI untuk meningkatkan sikap percaya dri dan hasil belajar tematik siswa.

\section{METODE}

Penelitian ini dilaksanakan di kelas II SD Negeri 1 Paningkaban pada Tahun Ajaran 2020/2021. Penelitian ini melibatkan siswa kelas II yang berjumlah 15 siswa, yang terdiri dari 11 siswa laki-laki dan 4 siswa perempuan.

Penelitian dilaksanakan di SD Negeri 1 Paningkaban yang berlokasi di Jalan Raya Gumelar-Ajibarang, Desa Paningkaban, Kecamatan Gumelar, Kabupaten Banyumas. Penelitian dilaksanakan dalam 2 siklus. Siklus I dilaksanakan pada tanggal 12 November 2020. Siklus II dilaksanakan pada 19 November 2020.

a. Siklus I

1. Rencana tindakan

Rencana yang peneliti lakukan di siklus I sebagai berikut:

a) Membuat lembar observasi sikap percaya diri

b) Membuat Rencana Pelaksanaan Pembelajaran (RPP)

c) Menyiapkan materi ajar

d) Menyiapkan soal evaluasi

e) Menyiapkan LKS

f) Menyiapkan sumber belajar

2. Pelaksanaan tindakan 
Dalam pelaksanaan tindakan, peneliti melaksanakan pertemuan sebanyak $1 \mathrm{kali}$ dalam setiap siklusnya. Pembelajaran dilaksanakan dengan menggunakan PMRI. Sintaks PMRI yaitu 1) memahami masalah, 2) menjelaskan masalah, 3) menyelesaikan masalah, 4) membandingkan dan mendiskusikan jawaban, 5) menarik kesimpulan. Media yang digunakan yaitu puzzle bangun datar dan papan bangun datar. Pada pertemuan 1 media yang digunakan yaitu puzzle bangun datar. Puzzle bangun datar adalah media pembelajaran yang terdiri dari delapan puzzle yang berbentuk bangun datar (persegi, persegi panjang, segitiga, jajargenjang, trapesium, belah ketupat, layang-layang dan lingkaran). Puzzle bangun datar diharapkan dapat membantu siswa mengenal bentuk-bentuk bangun datar. Pemilihan media disesuaikan dengan konteks Indonesia sebab peneliti menggunakan pendekatan PMRI.

3. Observasi

Peneliti melakukan kegiatan observasi dengan tujuan mengetahui tingkat keberhasilan maupun kendala yang dihadapi siswa selama mengikuti pembelajaran. Peneliti juga dapat mengetahui sikap percaya diri siswa selama mengikuti kegiatan pembelajaran melalui observasi.

4. Refleksi

Kegiatan refleksi dilakukan dengan tujuan mengevaluasi hasil dari kegiatan pembelajaran pada siklus I. Peneliti melakukan evaluasi mengenai tingkat keberhasilan belajar dan kendala yang dihadapi siswa selama mengikuti kegiatan pembelajaran. Apabila dalam refleksi terdapat aspek yang belum tercapai, maka dapat dilakukan perbaikan pada siklus II.

b. Siklus II

Kegiatan pembelajaran yang dilakukan pada siklus II secara umum tidak jauh berbeda dengan siklus I. Hal yang membedakan adalah pemberian tindakan melihat dari refleksi yang telah dilakukan pada siklus I. Peneliti menggunakan PMRI pada pelaksanaan kegiatan pembelajaran. Berikut ini langkah-langkah pembelajaran yang dilakukan pada siklus II:

1. Rencana Tindakan

Rencana yang peneliti lakukan di siklus II sebagai berikut:

a. Membuat lembar observasi sikap percaya diri

b. Membuat Rencana Pelaksanaan Pembelajaran (RPP)

c. Menyiapkan materi ajar

d. Menyiapkan soal evaluasi

e. Menyiapkan LKS

f. Menyiapkan sumber belajar

2. Pelaksanaan Tindakan

Dalam pelaksanaan tindakan, peneliti melaksanakan pertemuan sebanyak 1 kali dalam setiap siklusnya. Pembelajaran dilaksanakan dengan menggunakan PMRI. Sintaks PMRI yaitu 1) memahami masalah, 2) menjelaskan masalah, 3) menyelesaikan masalah, 4) membandingkan dan mendiskusikan jawaban, 5) menarik kesimpulan. Media yang digunakan yaitu amplop pertanyaan dan video pembelajaran bangun datar. Pada pertemuan di siklus 2 media yang digunakan yaitu amplop pertanyaan. Amplop pertanyaan adalah media pembelajaran yang terdiri dari dua puluh amplop, setiap amplop berisi pertanyaan yang berkaitan dengan materi SBdP (panjang dan pendeknya nada), Bahasa Indonesia (lingkungan tidak sehat) dan Matematika (bangun datar). Pemilihan media disesuaikan dengan konteks Indonesia sebab peneliti menggunakan pendekatan PMRI.

3. Observasi

Observasi dilakukan oleh peneliti dengan tujuan untuk mengetahui tingkat keberhasilan atau kendala yang dihadapi siswa selama mengikuti kegiatan 
pembelajaran. Peneliti juga dapat mengetahui sikap percaya diri siswa selama mengikuti kegiatan pembelajaran menggunakan lembar observasi.

4. Refleksi

Kegiatan refleksi dilakukan oleh peneliti dengan tujuan untuk mengevaluasi hasil kegiatan pembelajaran pada siklus II. Peneliti melakukan evaluasi terhadap keberhasilan belajar dan kendala yang dihadapi selama kegiatan pembelajaran. Peneliti membuat perbandingan data kondisi siklus I terhadap hasil belajar dan sikap percaya diri siswa dengan data kondisi siklus II terhadap hasil belajar dan sikap percaya diri siswa. Pedoman yang peneliti gunakan dalam membandingkan kedua data yaitu indikator keberhasilan yang telah ditetapkan.

\section{HASIL DAN PEMBAHASAN}

Pada siklus I pembelajaran dilaksanakan selama satu pertemuan. Pada tahap pelaksanaan, peneliti melaksanakan pembelajaran dengan menggunakan Pendidikan Matematika Realistik Indonesia (PMRI) dalam kegiatan pembelajaran. Pada kegiatan pembelajaran, peneliti membagi siswa menjadi 5 kelompok. Pembagian kelompok dilakukan dengan cara berhitung 1 sampai 5 . Setiap kelompok terdiri dari 3 siswa. Berikut ini adalah hasil belajar peserta didik pada siklus I yang bisa dilihat pada tabel berikut.

Tabel 1. Hasil Belajar Peserta Didik Siklus 1

\begin{tabular}{ccccc}
\hline \multirow{2}{*}{ Siklus 1 } & \multicolumn{2}{c}{ Tuntas } & \multicolumn{2}{c}{ Belum Tuntas } \\
\cline { 2 - 5 } & $\mathrm{Jml}$ & $\%$ & $\mathrm{Jml}$ & $\%$ \\
& 7 & $47 \%$ & 8 & $53 \%$ \\
\hline
\end{tabular}

Pada siklus I hasil kegiatan siswa melalui evaluasi didapatkan dari seluruh siswa sebanyak 15 siswa terdapat 7 siswa Tuntas dan 8 Belum Tuntas, dengan persetanse $47 \%$ dan $53 \%$. Berdasarkan pada siklus I maka diputuskan untuk melanjutkan perbaikan pada siklus II dikarenakan belum mencapai ketuntasan yang diharapkan. Berikut ini adalah hasil belajar peserta didik pada siklus II yang bisa dilihat pada tabel berikut.

Tabel 2. Hasil Belajar Peserta Didik Siklus 2

\begin{tabular}{ccccc}
\hline & \multicolumn{2}{c}{ Tuntas } & \multicolumn{2}{c}{ Belum Tuntas } \\
\cline { 2 - 5 } Siklus 2 & $\mathrm{Jml}$ & $\%$ & $\mathrm{Jml}$ & $\%$ \\
& 12 & $80 \%$ & 3 & $20 \%$ \\
\hline
\end{tabular}

Berdasarkan pada siklus II maka diputuskan bahwa siswa mengalami peningkatan ketuntasan sesuai yang diharapkan. Pada siklus II terdapat 12 siswa yang sudah Tuntas dan 3 siswa Belum Tuntas, dengan persentase $80 \%$ dan $20 \%$.

Dari 2 siklus yang sudah dilaksanakan selama 2 pertemuan dapat dipastikan bahwa model PMRI dapat meningkatkan hasil belajar peserta didik pada muatan pelajaran Matematika materi bangun datar. Menurut Susanto (2013:5) hasil belajar adalah kemampuan yang diperoleh siswa setelah mengikuti kegiatan belajar. Hasil belajar dalam penelitian ini adalah hasil belajar pada materi bangun datar. Depdiknas (2006:5) mengemukakan pembelajaran tematik adalah model pembelajaran terpadu yang menggunakan tema untuk mengaitkan beberapa mata pelajaran sehingga dapat memberikan pengalaman bermakna kepada siswa. Dalam hal ini tema 4 subtema 1 pembelajaran 4 yang mengintergrasikan mata pelajaran matematika, Bahasa Indonesia dan SBdP. Dalam penelitian ini, peneliti menggunakan pendekatan PMRI 
untuk membantu meningkatkan hasil belajar siswa. Menurut Shoimin (2013:150-151) mengemukakan lima langkah dalam pendekatan PMRI yaitu 1) memahami masalah, 2) menjelaskan masalah, 3) menyelesaikan masalah, 4) membandingkan dan mendiskusikan jawaban, 5) menarik kesimpulan Hasil belajar siswa dilihat berdasarkan soal evaluasi yang dikerjakan siswa pada pertemuan kedua setiap siklus. Berdasarkan data yang diperoleh terjadi peningkatan nilai pada hasil belajar siswa dalam setiap tahapan.

Dalam penelitian ini, terdapat beberapa kelebihan dan kekurangan. Berikut ini kelebihan dalam penelitian ini:

a. PMRI yang digunakan dalam Penelitian Tindakan Kelas membantu meningkatkan hasil belajar materi bangun datar siswa kelas II SDN I Paningkaban.

b. Media benda konkret yang menjadi ciri khas dari PMRI membantu siswa senang dan tertarik mempelajari materi bangun datar. Selain memiliki kelebihan, dalam penelitian ini juga terdapat beberapa kekurangan.

Berikut ini kekurangan dalam penelitian ini:

a. Penggunaan PMRI dalam dua siklus belum dapat meningkatkan sikap percaya diri siswa kelas II SD Kanisius Kotabaru.

b. Perlunya pembiasaan untuk membantu meningkatkan sikap percaya diri siswa sama seperti meningkatkan sikap atau karakter lainnya.

\section{SIMPULAN}

Berdasarkan hasil dan pembahasan, dapat disimpulkan sebagai berikut:

1. Upaya meningkatkan sikap percaya diri siswa kelas II SDN 1 Paningkaban dengan menggunakan Pendekatan Pendidikan Matematika Realistik Indonesia (PMRI) dengan langkah-langkah sebagai berikut: a) memahami masalah, b) menjelaskan masalah, c) menyelesaikan masalah, d) membandingkan dan mendiskusikan jawaban, e) menarik kesimpulan). Pada kondisi awal terdapat 4 siswa percaya diri, pada siklus I terjadi peningkatan jumlah siswa yang percaya diri menjadi 7 siswa dan pada siklus II meningkat kembali menjadi 11 siswa percaya diri.

2. Upaya meningkatkan hasil belajar pada materi bangun datar siswa kelas II SDN I Paningkaban dengan menggunakan Pendekatan Pendidikan Matematika Realistik Indonesia (PMRI) dengan langkah-langkah sebagai berikut: a) memahami masalah, b) menjelaskan masalah, c) menyelesaikan masalah, d) membandingkan dan mendiskusikan jawaban, e) menarik kesimpulan). Dari kondisi awal 66,66 dengan persentase ketuntasan $26,67 \%$, pada siklus I meningkat menjadi 68 dengan persentase ketuntasan $46,67 \%$ dan pada siklus II kembali meningkat menjadi 82 dengan persentase ketuntasan $80 \%$.

3. Pendekatan PMRI dalam pembelajaran dapat membantu siswa meningkatkan sikap kurang percaya diri menjadi cukup percaya diri dan meningkatkan hasil belajar siswa kelas II pada materi bangun datar.

\section{DAFTAR PUSTAKA}

Arifin, Zainal. 2009. Evaluasi Pembelajaran: Teori dan Aplikasinya. Bandung: PT Remaja Rosdakarya.

Aprinastuti, Christiyanti, dkk. 2017. Prototipe Modul Pelatihan Model Pembelajaran Van

Cangara, Hafied. 2011. Pengantar Ilmu Komunikasi. Jakarta: PT Raja Grafindo Persada.

Daryanto dan Tasrial. 2012. Konsep Pembelajaran Kreatif. Yogyakarta: Gava Media..

Fathurrohman, Pupuh, dkk. 2013. Pengembangan Pendidikan Karakter. Bandung: PT Refika Aditama. 
Ghufron, Nur \& Rini Risnawati. 2010. Teori-Teori Psikologi. Yogyakarta: AR - RUZZ MEDIA.

Hamalik, Oemar. 2013. Proses Belajar Mengajar. Jakarta: Bumi Aksara.

Hartinah, Siti. 2013. Pengembangan Peserta Didik. Bandung: PT Refika Aditama.

Haryono, Anung. 2012. Media Pendidikan Pengertian, Pengembangan dan Pemanfaatannya. Depok: Rajawali Pers.

Heruman. 2017. Model Pembelajaran Matematika di sekolah dasar. Bandung: PT Remaja Rosdakarya.

Hidayati, V.O. 2012. Peningkatan Aktivitas dan Hasil Belajar Materi Bangun Datar melalui Media Puzzle pada Siswa Kelas II Sekolah Dasar Negeri Kemandungan 03 Tegal. Skripsi. Semarang: Universitas Negeri Semarang.

Diakses dari https://lib.unnes.ac.id/19222/1/1402408172.pdf .

Hiele dalam Konteks Pendidikan Karakter untuk Sekolah Dasar. Yogyakarta: Sanata Dharma University Press 